\title{
AZ INTERSZUBJEKTÍV TUDÁS HATÁSA AZ FMEA ELEMZÉSRE
}

\section{THE INTERSUBJECTIVE KNOWLEDGE OF EFFECT FOR FMEA ANALYSIS}

\author{
Szamosi Barna ${ }^{1}$, Pokorádi László ${ }^{2}$ \\ ${ }^{1}$ Óbudai Egyetem Bánki Donát Gépész és Biztonságtechnikai Mérnöki Kar, \\ müszaki tanár, Magyarország 1081 Budapest, Népszínház u. 8.; +36704541851 \\ szamosi.barna@bgk.uni-obuda.hu \\ 2 Óbudai Egyetem Bánki Donát Gépész és Biztonságtechnikai Mérnöki Kar, \\ egyetemi tanár, Magyarország 1081 Budapest, Népszínház u. 8.; +36 309194929 \\ pokoradi.laszlo@bgk.uni-obuda.hu
}

\begin{abstract}
The objectivity is essential in the technical life, as well as in the engineering sciences. However objectivity is impossible where the human factor and the human subject can not be ruled out entirely. Sometimes use of the term itself is misleading, in science of safety or quality management etc. too. The authors intend to draw attention on it through a specific example in the study.
\end{abstract}

Keywords: objective, subjective; inter-subjective; risk analysis; FMEA.

\section{Összefoglalás}

A műszaki életben, így a mérnöki tudományokban is az objektivitás alapvető követelmény. Azonban olyan határterületeken, mint például a biztonságtudomány, vagy a minőségügy, ahol az emberi tényező az emberi szubjektum nem zárható ki teljes mértékben az objektivitás megvalósíthatatlan, és időnként maga a fogalom használata is félrevezető. A tanulmányban a szerzők egy konkrét példán keresztül erre a jelenségre kívánják felhívni a figyelmet.

Kulcsszavak: objektiv, szubjektiv, interszubjektiv; kockázatelemzés; FMEA.

\section{Bevezető}

A müszaki életben, így a mérnöki tudományokban is az objektivitás alapvetö követelmény. Azonban olyan határterületeken, mint például a biztonságtudomány, vagy a minőségügy, a technikai rendszerekben az emberi tényező az emberi szubjektum nem zárható ki teljes mértékben. Ezeken a fenti területeken a teljes objektivitás megvalósíthatatlan, és időnként maga a fogalom használata is félrevezető lehet. Cikkünkben erre a jelenségre kívánjuk felhívni a figyelmet, egy olyan Hibamód és hatás elemzés (FMEA) alapján amelyet, különböző szakértői csoportok ugyanazon eszközre, egy hétköznapi golyóstollra készítettek el. A kísérlet eredményei alapján talán nem túlzó az a véleményünk mely szerint az objektív helyett érdemes lenne a müszaki élet bizonyos területein is bevezetni és alkalmazni az interszubjektív fogalmát [1].

\section{Objektív, szubjektív, interszubjektív}

A kísérlet leírása és eredményének rövid értékelése előtt tisztázzuk azt, mit is értünk 
az objektív, a szubjektív és az interszubjektív fogalmakon.

\subsection{Objektív}

Az objektív szónak az online magyar értelmező szótárban több jelentése is található [2]:

- Személyestől független (hatás, jelenség, környezet), amely a tárgyi körülményekben rejlik, és a személy hatókörén kívül állónak tekintett körülményektöl függ.

- Tárgyilagos (döntés, állásfoglalás, vélemény), amit személyi szempontok, érzelmek, vélemények nem befolyásolnak, pártatlan, részlehajlás, elfogultság nélküli.

- Filozófia: A gondolkodástól függetlennek tekintett (világ, történés, jelenség, helyzet állapot, dolog).

Az objektivitás közkeletü felfogása szerint a dolgokat úgy kell bemutatni, hogy abba semmi szubjektív ne keveredjen, vagyis úgy, ahogyan önmagukban, az öket vizsgáló szubjektumtól függetlenül vannak. Alapvetően tehát az objektív a személytől vagyis a szubjektumtól teljesen függetlennek tekinthető állapotot jelent. Az objektív mint jelző, tehát bizonyos vonatkoztatási rendszerekben, mint például a müszaki életben a technikai rendszerek leírására alkalmas fogalom.

\subsection{Szubjektív}

A szubjektív szónak, mint fogalomnak az elöbb már hivatkozott online magyar értelmező szótár szerint három jelentése ismert [2]:

- A személyestöl függö (dolog), amely nem a tárgyi körülményekben rejlik, hanem rajtunk állónak tekintjük, tölünk függö körülményekböl ered.

- Saját személyes érzéseket kifejezö (megnyilatkozás, hangulat, lelkiállapot, kifejezés, dolog), amelynek alapja a személy lelkiállapota, hangulata.
- Nem tárgyilagos (vélemény, döntés, cselekedet, dolog), amely elfogult, egyéni hozzáállást, véleményt, állásfoglalást tükröz.

Alapvetően tehát a szubjektív fogalma teljesen ellentétes az objektív fogalmával.

\subsection{Interszubjektív}

Az objektivitás elve, egyes felfogások szerint, a tudományos megismerés alapelve. Ebből következően például az objektivitás mértéke (a szubjektivitáséhoz viszonyítva) a müvészi és a tudományos alkotás közötti fontos megkülönböztető jegynek számít. A tudományos megismerés alapkövetelménye, a ,tiszta” objektivitás igénye lett. Alapja a „tiszta”, értéket és érzelmet tekintve semleges racionalitás, továbbá a szubjektivitás elnyomása, eliminálása, beleértve ebbe a szubjektivitásnak a megismerés folyamatára és eredményeire történő vélelmezett deformáló hatásának semlegesítését is, írja Farkasová [3]. Ez a természettudományokban, így a müszaki tudományokban is meglévő elvárás fokozatosan áthatotta a társadalomtudományokat is, így aztán jelen van az olyan interdiszciplináris tudományokban is, mint a biztonságtudomány.

Ha az objektív megismerés teljes mértékben lehetséges volna, nem is objektív, hanem mindjárt abszolút ismeretekhez jutnánk. Ezzel szemben még a legegyszerübb dolgokról is csak korlátozott tudásunk lehet, mert csak bizonyos nézőpontokból az általunk konstruált modellek alapján ismerhetjük meg és írhatjuk le őket. Amennyiben a megismerés nem az objektum tökéletes, de a szubjektum oldaláról nézve passzív „leképződése", hanem a szubjektum és az objektum egyaránt konstitutív szerepet kap benne, akkor az interszubjektivitásnak tekinthető, írja Hankovszky [1] 


\section{Hibamód és hatáselemzés}

A Hibamód és hatáselemzés vagy röviden FMEA (Failure Mode and Effect Analysis), egy olyan elemzéses módszertan melyet azért alkalmaznak, hogy megbizonyosodjanak arról, hogy a termék- és folyamattervezés folyamatában a lehetséges problémák azonosítása és figyelembevétele megtörtént. Az eljárás a hibamegelőzés, a valószínüsíthető hibáknak a tervezési fázisban történő feltárásában és elháritásában játszik fö szerepet. Tulajdonképpen az elkövethető hibák, a hibák hatásainak, és azok okainak a gyüjteménye, kiegészítve a jelenlegi megelőzési eljárások és detektálhatóság vizsgálatával. Az eljárás egyfajta kockázat elemzés. A kockázatelemzés során kiszámítható a rizikó faktor szám (kockázati szám), az RPN (Risk Priority Number) a súlyosság $(\mathrm{S})$, gyakoriság $(\mathrm{O})$ és észlelhetöség (D) szorzata. Mivel mindhárom tényezöt egy 1 és 10 közti számmal jellemezzük, ennek nagysága 1-től 1000-ig terjedhet.

\section{A kísérlet eredményei}

A kísérlet során három főből álló szakértői csoportok végezték el ugyanolyan alkatrészekből álló golyóstoll FMEA elemzését. Minden csoport ugyanazokra az alkatrészekre és azok ugyanazon lehetséges hibáira 15 lehetséges hiba RPN számát állapították meg. Terjedelmi korlátok miatt cikkünkben csak négy RPN szám összehasonlítását mutatjuk be. Az első négy grafikon az elvégzett elemzések RPN számait tartalmazzák a különböző szakértői csoportok értékelései alapján. Az ábrákon a függöleges tengely az RPN számok skálája, a vízszintes tengely pedig az egyes szakértői csoportok betüjelét tüntettük fel.

Az 1. ábrán látszik, hogy az $\boldsymbol{A}, \boldsymbol{C}, \boldsymbol{D}$, szakértöi csoportok mindegyike egyaránt 96-os RPN értékeket adott. Azonban figyelemre méltó a $\boldsymbol{B}$ csoport RPN száma, amely kevesebb, mint a negyede az $\boldsymbol{A}, \boldsymbol{C}, \boldsymbol{D}$, csoport által adott értékeknek.

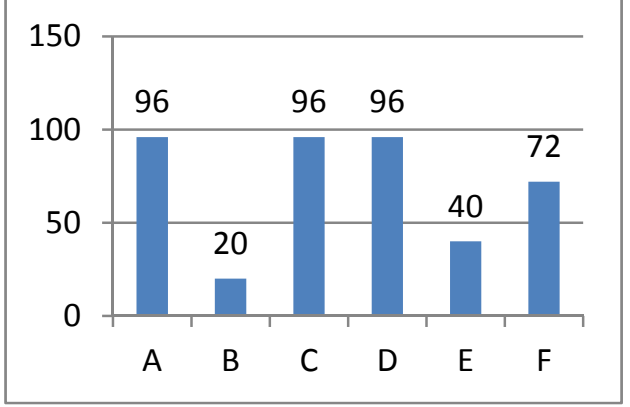

1. ábra. Az 1-es alkatrész RPN értékei szakértöi csoportok szerint

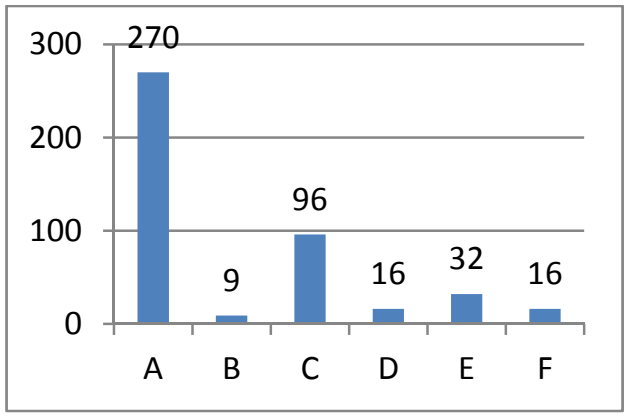

2. ábra. A 6-os alkatrész RPN értékei szakértői csoportok szerint

A 2. ábrán még szembetünőbb különbségek látszanak. A $\boldsymbol{B}, \boldsymbol{D}, \boldsymbol{E}$, és $\boldsymbol{F}$, szakértői csoportok RPN értékei is különböznek. Azonban a legjelentősebb különbség az $\boldsymbol{A}$, $\boldsymbol{C}$, szakértői csoportok rizikófaktor számainál látszik.

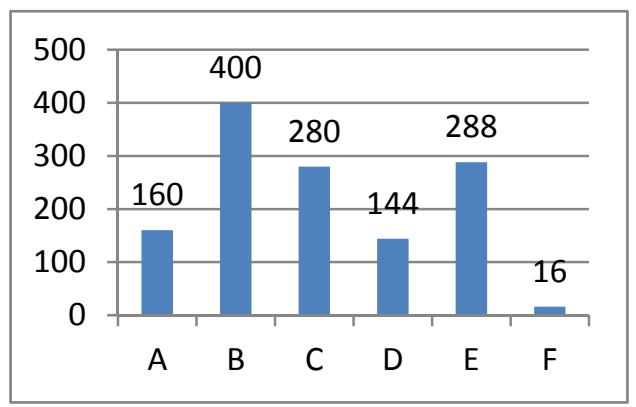

3. ábra. A 10-es alkatrész RPN értékei szakértöi csoportok szerint 
A 3. ábrán a $\boldsymbol{B}$ szakértői csoport által megállapított legnagyobb RPN szám 25ször nagyobb, mint az $\boldsymbol{F}$ szakértői csoport által adott legkisebb RPN szám. Figyelemre méltó az is, hogy az $\boldsymbol{F}$ szakértői csoport után következő második legkisebb RPN szám, amelyet a $\boldsymbol{D}$ szakértői csoport adott, 9-szer nagyobb a legkisebb RPN számnál.

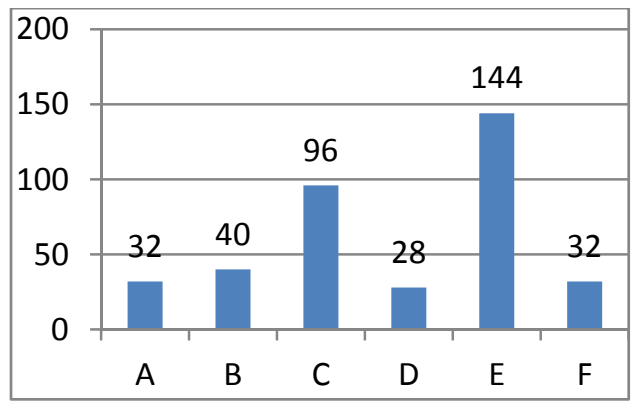

4. ábra. A 11-es alkatrész RPN értékei szakértői csoportok szerint

A 4. ábrán az $\boldsymbol{E}$ szakértői csoport által megállapított a legnagyobb RPN szám és a D szakértői csoport adott a legkisebb RPN szám. Itt nincs akkora különbség, mint az előző alkatrész legkisebb, és legnagyobb RPN értéke között, azonban itt is több mint négyszeres a különbség.

Az eddigi ábrákból is egyértelműen látszik, hogy az egyes szakértői csoportok eltérően ítélik meg az egyes alkatrészek rizikófaktor számait.

$A z$ 5. ábrában a függőleges tengelyen az RPN számokat, a vízszintes tengelyen pedig az alkatrészek számait tüntettük fel. Az ábrában a jobb áttekinthetőség érdekében a hat szakértői csoport által alkatrészenként meghatározott RPN számai közül csak hármat ábrázoltunk.

Az ábra így is jól mutatja, hogy az egyes szakértői csoportok mennyire eltérően ítélik meg ugyanazon alkatrészek rizikófaktorait.

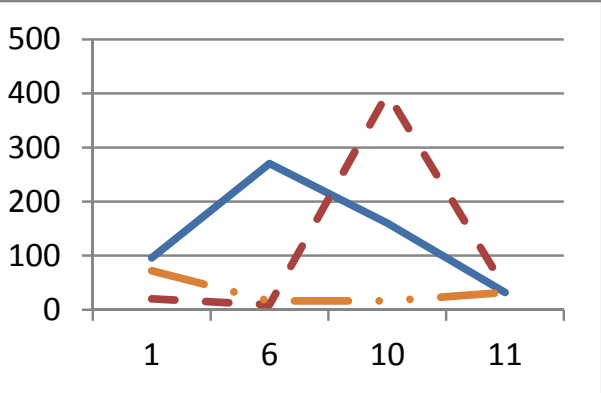

5. ábra. Három szakértöi csoport RPN számainak összehasonlitása

\section{5. Összegzés}

Az kísérlet jól példázza azt, hogy ugyanazon módszertani elemeken alapuló vizsgálat eredményét mennyire befolyásolja az egyes szakértői csoportok közös tudása. Véleményünk szerint tehát, ahol a szubjektum megjelenik, mint például a technikai rendszerek müködésének elemezésében, ahogyan a röviden bemutatott kísérletben végrehajtott FMEA-ban is, az eredmény nem kezelhető teljesen objektívként (hiába próbáljuk mi müszaki szakemberek mindenféle skálák bevezetésével objektívizálni), mert a döntés a szakértői csoportokban résztvevő személyek közös tudásától függ. Ilyen területeken helyesebb, ha az interszubjektív fogalmát használjuk.

\section{Szakirodalmi hivatkozások}

[1] Hankovszky Tamás: Az interszubjektivitás reménye, Apokaliptika és posztmodernitás, Szent Vince Szakkollégium, Piliscsaba,2009, p 77-78

[2] WikiSzótár.hu magyar értelmező szótár, http://wikiszotar.hu/wiki/magyar_ertelmezo_s zotar/ (2014.02.12.)

[3]E Farkasova Lehet (csak) objektiv a megismerés?, Kalligram, Pesti Kalligram Könyvkiadó és Könyvterjesztő Kft., Budapest, 1995 